\title{
Indigenous Knowledge-based Agrotourism in the Dayak Kenyah Community in Pampang Village, Samarida, East Kalimantan
}

\author{
Mardiany \\ Graduate School for Environmental Sciences, Brawijaya \\ University, East Java, Malang, Indonesia
}

\section{Mochtar Luthfi Rayes}

Faculty of Agriculture, Brawijaya University, East Java, Malang, Indonesia

\section{Zaenal Kusuma}

Faculty of Agriculture, Brawijaya University, East Java, Malang, Indonesia

\section{Luchman Hakim}

Department of Biology, Faculty of Mathematics and Natural Sciences, Brawijaya University, East Java, Malang, Indonesia

\section{Abstract}

This paper aims to describe recent tourism activity in Pampang villages and promote indigenous knowledge-based agrotourism in the Dayak Kenyah community in Pampang Village, Samarinda, East Kalimantan. The study found that Dayak culture is the main attraction for tourism in Pampang villages. Agricultural activity by the local people involves indigenous knowledge, but this has not been involved in the village tourism program development. The indigenous culture in farming has the potential of being introduced in tourism. Indigenous knowledge will contribute to the uniqueness, authenticity, and sustainability of agrotourism in the Dayak community. Some crucial problems related to this indigenous knowledge-based agrotourism in the Dayak Kenyah include lack of human resources and stakeholders' support. Systematic program planning to improve human resources should be able to increase knowledge, skills, and local capacity.

\section{Keywords}

Indigenous people, community-based tourism, bioculture conservation, sustainable farming 


\section{Introduction}

A recent discussion on development argues that the indigenous knowledge of the local community in managing the local ecosystem and the sustainability of resources is one of the important strategies to achieving a sustainable living system in the biosphere and to minimizing environmental degradation. An attempt to explore the indigenous knowledge has been promoted to provide comprehensive information related to the philosophical and practical aspects related to the social practices of using resources sustainably. Scholars have pointed out that indigenous knowledge contributes to the local community participation and support in this development program. Indigenous knowledge provides an abundance of information about plants, animals, and the ecosystem characteristics and techniques to uses natural resources sustainably. A lot of attention has been paid in many works of indigenous knowledge to the medical plant, and many research results have been reported, contributing to the recent drugs finding (Howes, 1979; Briggs, 2005; Sen, 2005). Scholars have pointed out that one of the places to find indigenous knowledge is in developing countries, especially in Asia, Africa, and southern America. An abundance of indigenous community groups in these areas potentially provides much valuable indigenous knowledge, which can be adopted and promoted to enhance sustainable living systems in the earth (Warren, 1996; Kapoor \& Shizha, 2010).

Traditional knowledge in many countries, however, is facing severe problems. Scholars have identified that a decrease in conventional knowledge is a complex phenomenon. Forest degradation and biodiversity reduction have been reported as one of the factors contributing to the decline of traditional knowledge practices. The decrease in the diversity of plants as raw materials in many areas has been a contributor to the decrease of traditional healing. Modernization has been viewed as one of the crucial aspects of the decline in conventional knowledge practices (Ramirez, 2007; Reyes-García et al., 2013). In many developing countries, modernization is one of the crucial steps toward modern society. Modernization has arrived and become involved in many aspects of modern human life, including areas of medicine and farming. Ramirez (2007) points out four causes for the loss in the recent era of traditional knowledge. His study encompasses aspects related to: (1) rapid development in areas with high traditional knowledge and practices; (2) displacement of local community for development, including tourism; (3) the indigenous community was forced to move from their lands; and (4) the past purchasing of land by foreigners in the home areas of indigenous people.

Issues of tourism development to support the indigenous community have emerged in response to an increase and integration into recent trends of tourism growth the potential value of the outstanding indigenous people's culture and nature (Butler \& Hinch, 2007; Butler \& Menzies, 2007; Hakim, et al., 2012). Exploring traditional knowledge to support the sustainable tourism sector in the local community in developing countries has been important (Johnston, 2000; Carr et al., 2016). Principally, traditional knowledge contributes to environmental conservation, in which it has become the fundamentals aspect in issues of sustainable tourism. Traditional culture has a huge story in each practice, and it is becoming an essential material for tourism interpretation. This interpretation has recently become an important issue in ecotourism. Through analysis, it is expected that tourists will be aware of environmental issues. Traditional knowledge contributes significantly to the formation of cultural landscapes.

Indigenous knowledge-based agrotourism refers to the development of agrotourism based on local people's knowledge in agricultural aspects. Agrotourism is a form of tourism focusing on the farming sectors. Agrotourism is especially important to increase farmer income through innovative product diversification in rural areas (Adam, 2004; Sznajder et al., 2009). The economic impact of agrotourism in numerous areas is significant, and a recent trend shows that 
agrotourism has grown significantly as a tool in rural development (Ramsey \& Schaumleffel, 2006; Drăgulănescu \& Druţu, 2012). Agrotourism provides opportunities for farmers to open new businesses based on farmland and farming culture, including farm tours, farmer's markets, agricultural festivals, and culinary activities. There are also opportunities for bicycle trails, horse riding, fishing, boating, and hiking trails (Sznajder et al., 2009). Agrotourism has been viewed as one of the crucial machines for economic growth in many areas in developing countries.

Exploring links between traditional knowledge, agrotourism, and tourism is crucial for the indigenous community and the preservation of its cultural aspects. There is potential mutualism among traditional culture, agrotourism, and tourism that is crucial to the support of local development. Agrotourism and tourism are the keys to increase income to support traditional knowledge preservations. In contrast, traditional knowledge will help the quality of agrotourism through its sustainable agricultural practice and high-quality agrarian product. Scholars have pointed out that agrotourism contributes to the promotion of nature conservation (Dumitraș, 2013; Khamung, 2016; Addinsall et al., 2017). Farmland management should be able to meet tourism needs in the high quality of environmental standards. This includes beautiful scenery, maintaining diversity, and the provision of free-chemical agricultural products.

The Dayak Kenyah are one of the indigenous communities in East Kalimantan. Administratively, the recent population was living in Pampang villages in Samarinda. The tourism website of the East Kalimantan Regency (https://kaltimprov.go.id/kategori/wisata-unggulan) promotes Pampang villages as one of the tourism sites. Pampang villages have potential agricultural resources of which few are involved in tourism development. The development of tourism in Pampang villages offers a strategic position for the promotion of the local lives of the Dayak, especially local culture related to the use of the environment and its natural resources. The aim of this study is to describe the recent tourism activity in Pampang villages, describe the identity of the Dayak in Pampang villages, and describe the indigenous knowledge of the Dayak in Pampang villages, all of which are important to support tourism development.

\section{Methods}

A field survey was done in Pampang villages, Samarinda City, in East Kalimantan. Located in the equator line, the climate of the Pampang area is a tropical rain forest with high humidity. In the past, the landscape of the Pampang area was dominated by the Dipterocarpaceae forest with tall trees, lianas, and plants with wide leaves. The Dayak Kenyah inhabits recent Pampang villages. Administratively, the villages cover an area of about $\pm 3,834,2$ hectares. There are numerous land-use types, including shrubs, uplands rice field, orchards, mixed gardens, mining areas, and settlements (Fig. 1).

A preliminary survey was conducted through a literature study. The focus of the document examination was the objectives of the study, including: (1) documents related to tourism in East Kalimantan, especially in Samarinda and Pampang villages; (2) history of the Dayaks community in the Pampang villages; and (3) socio-cultural information of the Dayak community, especially the community in East Kalimantan. We visited the governmental office of East Kalimantan and the office of tourism of the East Kalimantan Regency in Samarinda City.

Field observation was done in the area of the villages. The inspection was a focus on describing recent tourism activity in Pampang villages, identifying agrotourism potential, and identifying the list of stakeholders and groups in the tourism area. A potential agrotourism survey was done through village resources related to explorations of agriculture. The 
component of fascinating landscapes of villages was listed, visited, and documented. Interviews were done in the village areas during the dry periods of 2018. Informants of the study included informal leaders of the Dayak community in Pampang (locally called ketua adat), the village head, village secretary, the coordinator of Dayak art and performance, and a farmer. The authors had opportunities to conduct interviews with an old man in the community. The interviews were conducted in Bahasa Indonesia and the local language. Community knowledge of the agricultural practices and rituals refers to the qualitative data on the informant's views about the traditional knowledge related to farming activity. Data were analyzed descriptively.
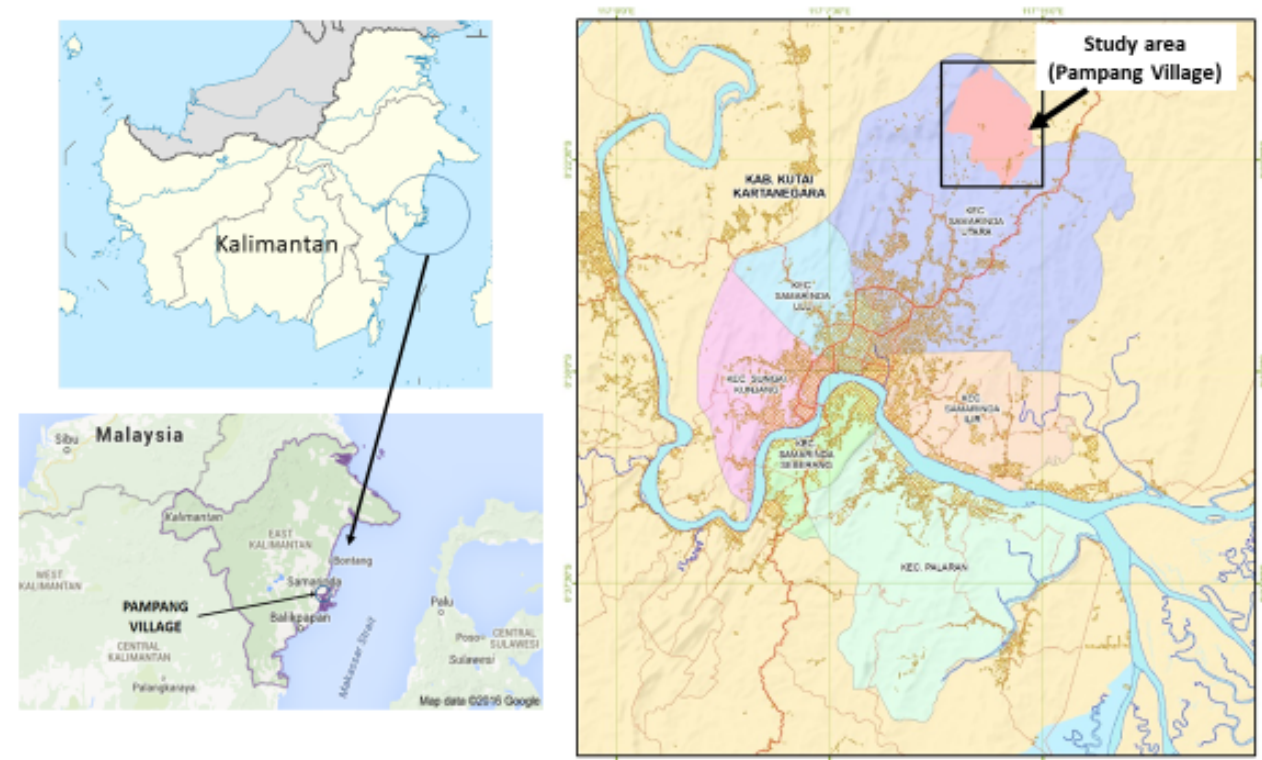

Fig 1. The location of Pampang Villages in Samarinda, East Kalimantan

\section{Result and Discussion}

\section{Tourism and local culture in Dayak Kenyah in Pampang Village}

In East Kalimantan, tourism grows significantly (Fig. 2). An abundance of natural and cultural resources contributes significantly to attract domestic and international tourism to explore the nature and culture of East Kalimantan. Natural tourism attractions consist of tropical forests, waterfalls, rivers, wildlife, and sandy beaches. Nature-based tourism contributes significantly to the tourism industry in East Kalimantan. The primary resources supporting nature-based tourism include a substantial tropical rain forest, which is home to numerous plants and animals. Many species are endemic to Kalimantan Island, and some of them are flagship species in both conservation and tourism, including Orangutans (Pongo pygmaeus) and Sun bear (locally called Beruang madu, Helarctos malayanus). Small islands in East Kalimantan also contribute significantly to attract tourists, such as the Derawan islands chains (https://www.lonelyplanet.com/indonesia/kalimantan). 
Cultural sites for recreation have been identified in abundance, including the traditional longhouse of the Dayak (rumah panjang). In East Kalimantan, tourism with indigenous and native Dayak settlements has been identified as growing in several areas, such as in Pampang Village (East Samarinda City), Kampung Purbakala Merabu (Berau), and Rumah Lamin Mancong (West Kutai). In these areas, the longhouse as the Dayaks' cultural heritage is the main tourism object. Traditional woven fabric (kain tenun), bamboo weaving, and wood carvings that were produced by the Dayak community were the typical souvenirs.

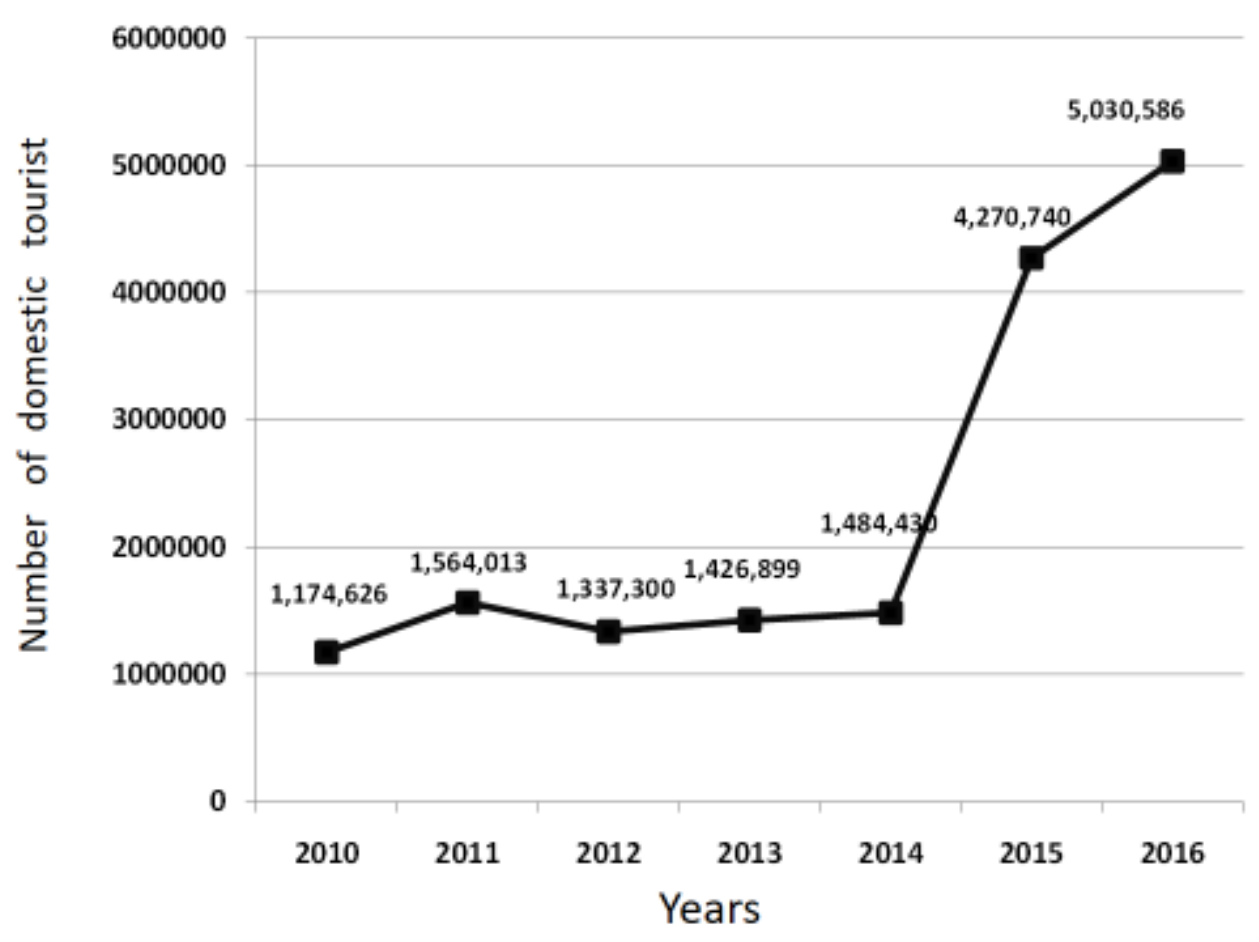

Fig 2. Numbers of domestic tourism in East Kalimantan

The initial declaration of Pampang as a village tourism area was made in June 1991 by the East Kalimantan Governor, Mr. H.M. Ardans. The statement of the Pampang area as a tourism site in East Kalimantan was the strategy to introduce the Dayak community and its culture to tourism. The rich cultural event in local community is the primary consideration for the declaration of Pampang as a rural tourism area. As a consequence of the declaration of the Pampang villages as a rural tourism area, development assistance was undertaken. The development of infrastructure was also supported to increase the quality of tourism attractions in Pampang. Cultural exhibitions recently became a magnet for the tourism industry in the Pampang area (Fig. 3). The center of cultural presentations was made in the Pampang longhouse. Pampang is one of the international tourist destinations in Samarinda City (Schiller, 2001; Mardiany, 2017). The cultural tourism development in Pampang has not been without potential problems. Informants point out that the benefits of tourism to the local community should be increased, and many people should be involved in tourism activity. Community-based tourism should be promoted. 


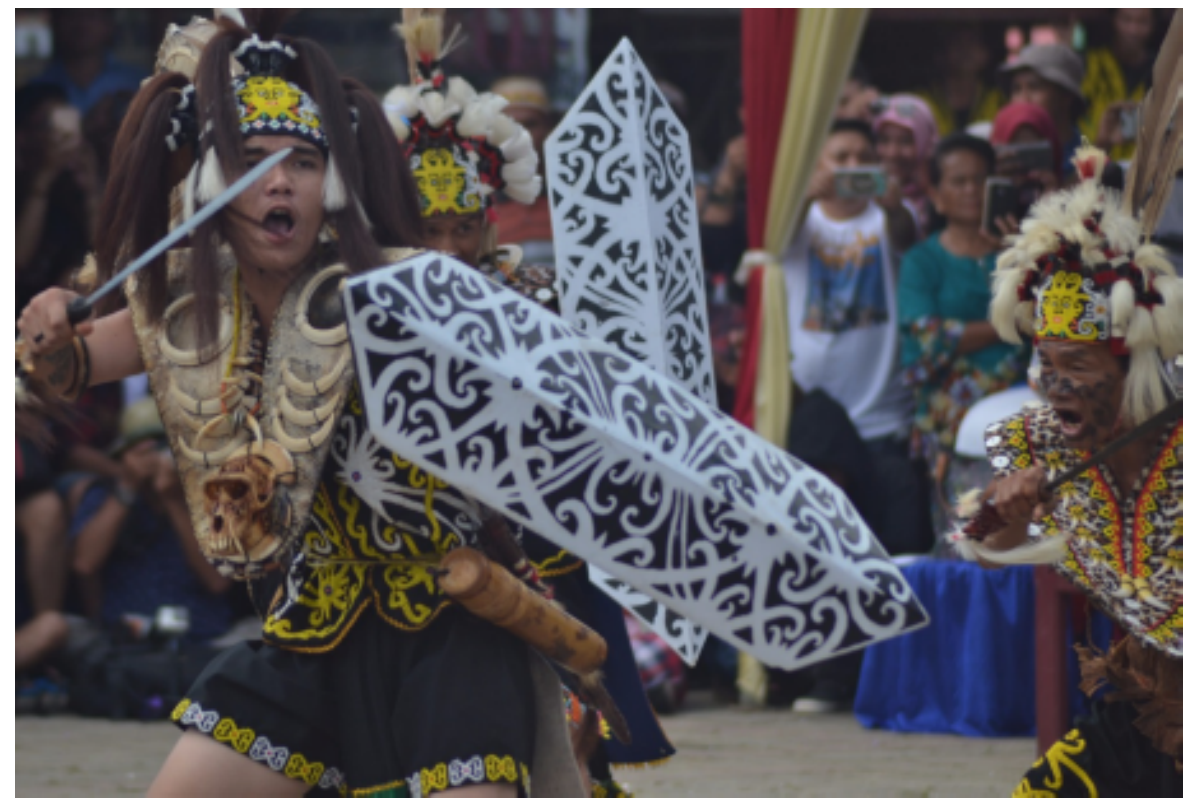

Fig 3. Cultural events as main tourism attraction in Pampang Village

\section{Socio-ecological aspects of Dayak in Pampang Village}

The Dayaks are one of the major ethnic groups in Kalimantan Island. The Dayaks are the indigenous ethnic group of Kalimantan Island. The traditional and religious belief was called Kaharingan, as local a belief. The Kaharingan is one of the essential identifications for the Dayak, especially for Dayaks living in the center of Kalimantan Island. New modern religious groups classify the Kaharingan belief as Hindu, or they are called Hindu Kaharingan. Dayaks are close to Shamanism, the old way of life and tradition. The Shamanism in Dayaks leads to the closer spiritual connection of humans and nature (Baier, 2007; Darmadi, 2017; Gepu et al., 2018).

Most of the community has traditionally lived along with the river system in Kalimantan Island. The river is a vital landscape component among the Dayaks, especially for transportation. For most of the Dayak clan, the river system is the landscape's instrument to enhance clan dispersal. These lead to the development of settlements along rivers. In many cases, streams have been used as economic corridors, in which local people harvest crops and fruit and sell them to the nearest market through the rivers as being the corridors of movement. Therefore, the rivers play an essential role in local economic activity. Cultivating crops has been done through the slash and burn system within a large area of the clan or the group community (MacKinnon et al., 1996).

Culturally, the concept of "village" is the new administrative organization. In the past, the Dayak community lived in clans, and they have a territory area lead by its leader. The Dayaks lived in a longhouse (locally called Rumah Panjang or Rumah Betang) as a communal house system. There are numerous socio-cultural functions of a longhouse, including the transfer of knowledge of multiple skills to enhance community life (MacKinnon et al., 1996).

From document analysis and confirmation by the respondent, Pampang was established as a settlement area by the Dayak Kenyah in the beginning of the 1960s. Some documents state that the Dayak community originated from migration from the Apo Kayan highland, the city located at the recent border of Malaysia and Indonesia in East 
Kalimantan Island. Other documents describe that, in 1973, the man called Jawi Ngau had a collaboration with Kuling to make ironwood beams in Pampang. In this opportunity, Jawi Ngau opened farmland to start the agricultural activity. In 1977, there were reports of five families of Dayak Kenyah living in Pampang, including the Jawi Ngau family. In 1980, 10 families from the Long Payau in Apo Kayan highlands came to Pampang. In 1981, five families from Leka Kidau arrived and became new members of the community in Pampang. In 1982, four families of the Dayak Kenyah came to Pampang.

The recent population of the Dayak Kenyah in Pampang lived in an agricultural-based ecosystem. Besides settlement, secondary tropical forest, wet paddy rice, uplands rice fields, orchards, plantations, and home gardens were found in the Pampang Village area. Social organization was adopted according to national rules, and numerous concepts of modernization have been introduced as a mechanism to manage the community.

\section{Agrotourism potentiality}

Agrotourism potential in the Pampang area includes the traditional agricultural system, agricultural landscape systems, and farming products.

\section{Traditional agricultural system}

In the past, slash and burn agriculture has been the conventional farming practice among the local community in Kalimantan Island, especially among the Dayaks. While many scholars point out that slash and burn agricultural practices contribute to forest degradation (Tinker, et al., 1996, Kiyono, 2000; Yadav et al., 2012), some scholars point out that this practice is one of the old sustainable agricultural practices (Kleinman et al., 1995; Fox, 2000). In another argument, Padoch \& Pinedo-Vasquez, (2010) argue that slash and burn agriculture practiced by the indigenous community is principally able to support local biodiversity conservation. Previous reports relating to the traditional integrated farming system in the Philippines confirmed that Hanunoo swidden agricultural practices can maintain and support numerous crop species and local rice varieties (Conklin, 1957).

Some of the complexes step in slash and burn agriculture reduce the high pressure of weeds and provides opportunities for seeds to grow. Local people use fire to open habitats to start cultivation in selected areas. According to the informants, fire is an active agent to reduce and cut the reproduction cycle of pests. The indigenous knowledge of the indigenous community allows for a comprehensive knowledge of the landscape structure, climates, plant and animal usage, and other biodiversity characteristics (MacKinnon et al., 1996; Crevello, 2004). The practice of slash and burn has often been a source of tension between local people, local government, conservationists, and central government.

According to the informants, modern cultivation of crops and rice in the Pampang area has been implemented through "rotation cultivation". The informant pointed out that "slash and burn" the Dayak no longer practices farming in Pampang villages. The informant stated that there are significant differences between the slash and burn agricultural practices and rotation cultivation, which were implemented by the Dayaks in Pampang villages (Table 1). The informant pointed out that rotation cultivation began with a decrease in forest area for traditional farming and the establishment of numerous land tenure laws, where lands were placed under permanent state control. 
Table 1. Difference between slash and burn agricultural cultivation and rotation cultivation

\begin{tabular}{|l|l|}
\hline \multicolumn{1}{|c|}{ Slash and burn } & \multicolumn{1}{c|}{ Rotation cultivation } \\
\hline $\begin{array}{l}\text { Slash and burn was practiced in large area. This cultivation method is possible to practice } \\
\text { since a large area is available. The slash and burn often take place in adat lands, a specific } \\
\text { territory of a particular clan. }\end{array}$ & $\begin{array}{l}\text { Rotation cultivation was implemented in a limited area. } \\
\text { Recent administrative system organized Dayak } \\
\text { community into a definitive area and did not allow them to } \\
\text { cultivate beyond the settlement area, including the forest } \\
\text { under the control of the provincial or central government. }\end{array}$ \\
\hline $\begin{array}{l}\text { Dayaks live like nomads, without a definitive place. Dayaks can explore and move in a wide } \\
\text { area of forest within the clan territory. }\end{array}$ & $\begin{array}{l}\text { Dayaks live in the settlement area, officially registered as } \\
\text { a member of village dwellers. }\end{array}$ \\
\hline $\begin{array}{l}\text { Cultivation pattern: Cutting and burning plant biomass in forestlands to open the agricultural } \\
\text { field. The downed plant biomass was left to dry and burn. These practicess provide rich soil } \\
\text { nutrients and reduce pests. After lands become available, farmers cultivate crops. Within five } \\
\text { years, the soil nutrients decreased and led the farmers to abandon the field and move to a } \\
\text { new area. Long fallow periods. Repeating the cycle may take 20 years. }\end{array}$ & $\begin{array}{l}\text { Cultivation pattern: Short fallow period. Rotation within a } \\
\text { relatively small area in the definitive village area. }\end{array}$ \\
\hline
\end{tabular}

Traditional knowledge has been identified as being crucial among community members of the Dayak Kenyah in Pampang Village. Several rituals have been identified. Rituals represent the spiritual relationship between people, ancestors, and nature. Scholars point out that rituals are important among the traditional community (Cannadine \& Price, 1992). The dynamic and sensitive culture of the Dayak community is perhaps the most crucial issue facing the government and the provincial tourism office. In the recent era, modern agricultural trends can impact on local culture and, therefore, contribute to the social changes, including loss of traditions and rituals in farming. Moreover, slash and burn, as well as rotation farming is particularly sensitive to environmental issues, including global warming.

Agricultural landscapes systems

The recent agricultural landscape system in Pampang involves the combination of socio-ecological functions. In the past, the tropical rain forest has been converted into man-made landscapes, such as areas for crops cultivation and human settlements (Fig. 4). Recently, mining is one of the few activities that has influenced aspects in some areas.

The settlement of the Dayak Kenyah in Pampang villages has been influenced by modernization. This can be observed from the modern building of houses. A family lives in private houses, and there is no evidence of Dayaks living in the longhouse. The longhouse exists in the villages and recently became an iconic building for the community living in Pampang. The main function of the longhouse recently is the cultural building. The cultural activities and performance, which were conducted at the longhouse, lead to the area becoming a spot for culture-based attractions in Pampang. A single house often has home gardens with numerous plant species, including coconut and various trees species.

Farmlands are an important landscape component for the Dayak Kenyah in Pampang villages. Some important crops are cultivated in Pampang villages. Some of these have been crucial as food, while some plants have been cultivated to support the income of household. In the mix garden ecosystem, numerous fruit tree species are grown. The plant diversity, vegetation structure, and function provide opportunities for conservation of ecosystems. Among the Dayak community, the mixed garden has been managed through the traditional knowledge system, and it has become a crucial patch to supporting local and regional landscape sustainability (MacKinnon et al., 1996; Polosakan \& Soedjito, 1997; Rahu et al., 2013). 


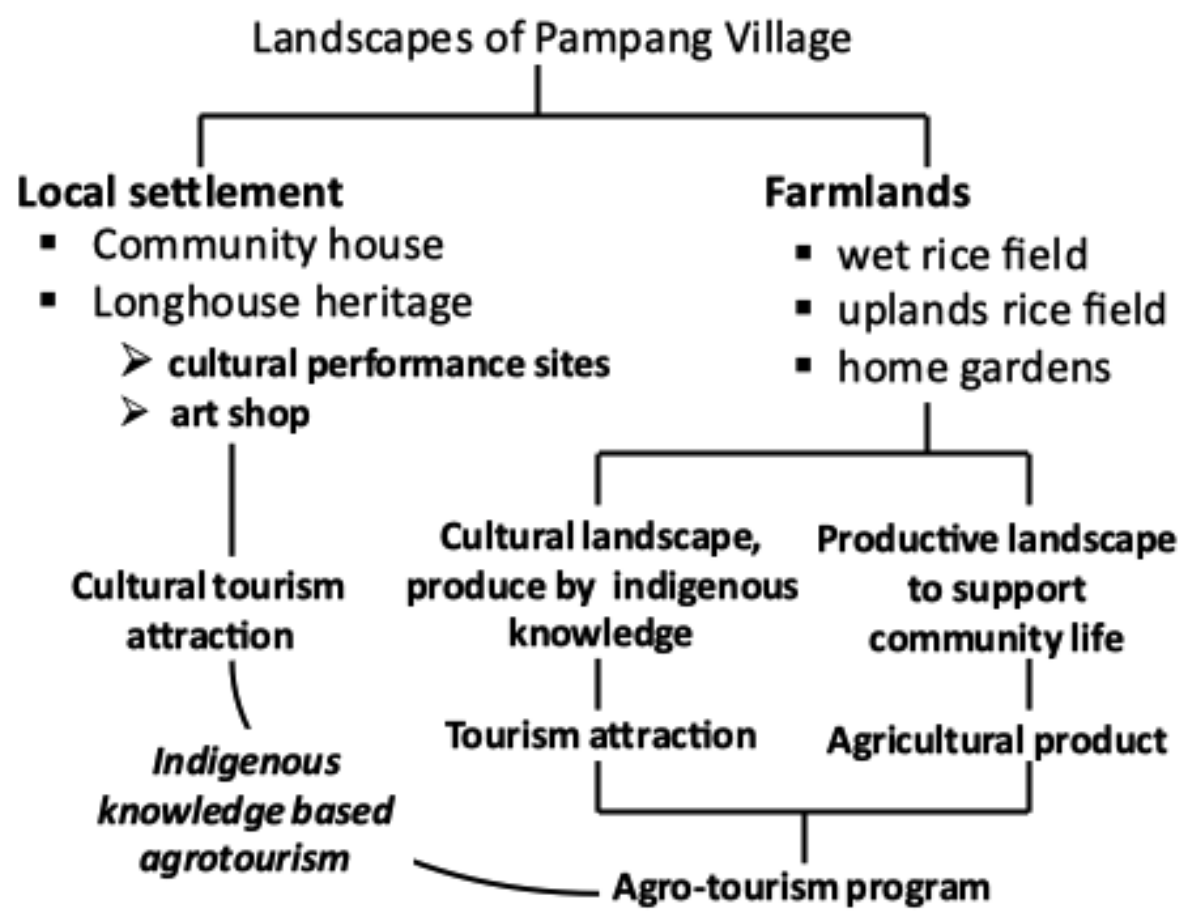

Fig 4. The landscapes of the Dayak Kenyah in Pampang Villages and their opportunities for agrotourism development.

Rice and Bawang Tiwai are important crops. Rice is an important staple food among the Dayak Kenyah in Pampang, where it is cultivated through the traditional cultivation system (Fig. 5). The gardens of the Dayak Kenyah in Pampang are home to numerous fruit plants. Among the potential fruit trees were Durians. Lay (Durio kutejensis), one of the local durian cultivars, were in abundance in Pampang villages. Agricultural products are in abundance, but few have been involved in the tourism program in Pampang villages. According to the IUCN Red List of Threatened Species, which was published in 1998, Durio kutejensis has been classified into the vulnerable categories with general information on recent population trends. Durio kutejensis is native to Kalimantan Island, and the current population has been severely fragmented. Rapid degradation of forest and changes in traditional plantation among the Dayak community seem responsible for the decrease of the population in the wild.

It is important to note that the belief system among the Dayaks is a significant contributor in the Dayak's daily lives, including in agricultural practices. The belief system among the traditional community argues that nature is an integral part of the human living system, and therefore should be appreciated. Disturbance to the natural system will affect community members through numerous negative impacts. The appreciation of Dayaks for nature has been shown by the declaration of particular lands and vegetations as sacred sites. Ecologically, this has allowed biodiversity to be conserved and able to provide numerous ecological services to the community surrounding the sacred area. 


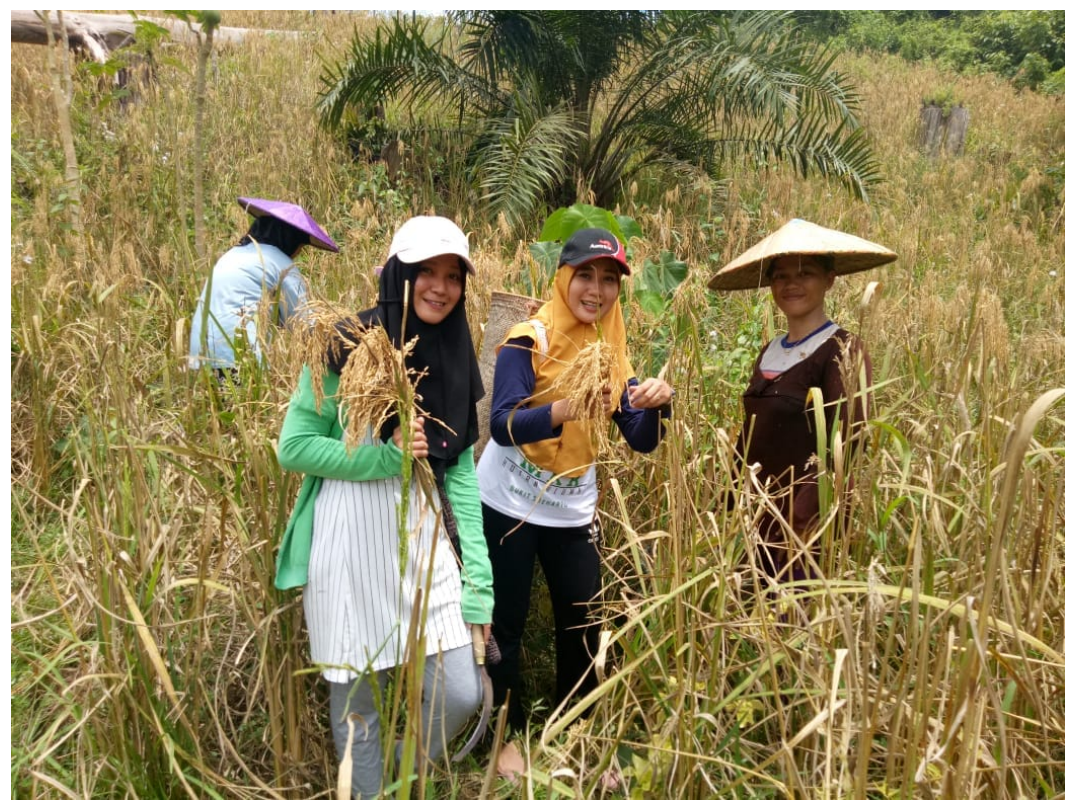

Fig 5. Harvesting in upland paddy field

\section{Developing indigenous knowledge-based agrotourism}

Recent tourism issues discuss the relationship between the indigenous community and tourism. It is the fact that tourism resources located in the habitat of the particular indigenous communities provide benefits for the prosperity of community members. Scholars point out that indigenous communities are often related to the city with less access to education, health, and economic activities. Located in the remotes area, the indigenous communities are often supported by poor infrastructure in support of development (Hall \& Patrinos, 2012). The indigenous community in tropical countries with high biodiversity is often poor and experiences severe problems in its population sustainability. A similar situation was observed in the Dayak city in Kalimantan. It has been discussed that tourism should be able to support the indigenous community to live. Tourism can stimulate economic activity, which is important to increase the financial income of households. Community-based tourism has been promoted as an important instrument to enhance the local benefits from tourism (Butler \& Hinch, 2007; Hakim, et al., 2012; Carr, et al., 2016).

Liking traditional knowledge and tourism has recently been discussed as an alternative strategy in tourism development (Butler \& Menzies, 2007). In agrotourism development, the contribution of traditional knowledge will increase the competitiveness and sustainability of agrotourism (Khanal \& Shrestha, 2019). Through traditional knowledge, the attractions and products of agrotourism will have specific uniqueness and rich traditional value. They will become an interesting aspect for attraction of tourists to particular agrotourism sites. Almost all areas with outstanding and preserved cultural attributes now attempt to involve local culture and tradition in agrotourism development.

So far, agricultural products of local dwellers have not been involved and integrated into recent tourism activity in Pampang villages. The opportunities for the involvement of farming products shortly encompass farm tours and traditional market festivals. Farm tours offer opportunities for tourists to explore agricultural lands and farmer activities in farmland areas. In such cases, comprehensive spatial data and information is needed. Indigenous knowledge related to agriculture should be integrated as a fundamental aspect of spatial tourism planning and development. It is especially 
important to increase the value and uniqueness of such agrotourism sites. The most common goal of the farm tourism program in practice is to increase tourist knowledge of farming activities and local agricultural products. A traditional market is an important event for the promotion of crops and fruits, which are cultivated by the local people in Pampang villages.

Human resources capacity has been identified as a barrier for the development of indigenous knowledge-based agrotourism in the Dayak Kenyah community in Pampang villages. The lack of technical programs has been consistently cited by the informants. This situation is similar to those of the numerous communities in developing countries.

Government bureaucracies and poor coordination among responsible offices for development have been cited as crucial factors for the limitation of agrotourism development. Given the reality of the administrative barriers, a major challenge is how to foster community participation in agrotourism development.

\section{Conclusion}

Pampang villages have experience with cultural tourism. Enhancing agrotourism development in Pampang villages is crucial, especially to provide an alternative economic income to the local community. Samarinda City, the location of Pampang villages, is a capital city in East Kalimantan in an area of intense coal mining. Cultural tourism in Pampang villages has a positive impact on on local economic activity and, importantly, can preserve the cultural aspect of the Dayak Kenyah in East Kalimantan. The development of agrotourism-based indigenous knowledge has the potential to develop in Pampang villages. The development will succeed only if the local government, planners, and community work together and are able to establish proper planning to meet sustainable tourism activity in Pampang. The challenges of indigenous knowledge-based agrotourism in the Dayak Kenyah community in Pampang villages are lack of community knowledge on tourism development issues and skills. The right of the local people to participate and be involved in tourism should be accommodated in tourism development.

\section{References}

Adam, K.L., 2004. Entertainment farming and agri-tourism. The National Center for Appropriate Technology (NCAT), Arkansas.

Addinsall, C., Weiler, B., Scherrer, P., Glencross, K., 2017. Agroecological tourism: bridging conservation, food security and tourism goals to enhance smallholders' livelihoods on South Pentecost, Vanuatu. Journal of Sustainable Tourism, 25(8): 1100-1116.

Cannadine, D., Price, S., 1992. Rituals of royalty: power and ceremonial in traditional societies. Cambridge University Press.

Carr, A., Ruhanen, L., Whitford, M., 2016. Indigenous peoples and tourism: the challenges and opportunities for sustainable tourism. Journal of Sustainable Tourism, 24(8-9): 1067-1079.

Conklin, H.C., 1957. Hanunoo Agriculture. A Report on an Integral System of Shifting Cultivation on the Philipines. FAO, Rome, Italy.

Baier, M., 2007. The Development of the Hindu Kaharingan Religion: A New Dayak Religion in Central Kalimantan. Anthropos, 2: 566-570.

Briggs, J., 2005. The use of indigenous knowledge in development: problems and challenges. Progress in development studies, 5(2): 99-114. 
Butler, R., Hinch, T., 2007. Tourism and indigenous peoples: Issues and implications. Routledge.

Butler, C.F., Menzies, C.R., 2007. Traditional ecological knowledge and indigenous tourism. In Tourism and Indigenous Peoples (pp. 33-45). Routledge.

Carr, A., Ruhanen, L., Whitford, M., 2016. Indigenous peoples and tourism: the challenges and opportunities for sustainable tourism. Journal of Sustainable Tourism, 24(8-9): 1067-1079.

Crevello, S., 2004. Dayak land use systems and indigenous knowledge. Journal of Human Ecology, 16(1): 69-73.

Darmadi, H., 2017. Dayak Asal-Usul dan Penyebarannya Di Bumi Borneo. Sosial Horizon: Jurnal Pendidikan Sosial, 3(2): $322-340$.

Dumitraș, D.E., Muresan, I.C., Ilea, M., Jitea, I.M., 2013. Agritourism-A Potential Linkage Between Local Communities and Parks to Maintain Sustainability. Bulletin of University of Agricultural Sciences and Veterinary Medicine Cluj-Napoca. Horticulture, 70(2): $300-309$.

Drăgulănescu, I.V., Druţu, M., 2012. Rural tourism for local economic development. International Journal of Academic Research in Accounting, Finance and Management Sciences, 2(1): 196-203.

Fox, J., 2000. How blaming "slash and burn" farmers is deforesting mainland Southeast Asia. AsiaPacific issues, Honolulu.

Gepu, W., Suda, I. K., Suyasa, I.M., 2018. Religious conversion towards Hindu Kaharingan to Christianity. International Journal of Linguistics, Literature and Culture, 4(4): 25-37.

Hakim, L., Soemarno, M., Hong, S.K., 2012. Challenges for conserving biodiversity and developing sustainable island tourism in North Sulawesi Province, Indonesia. Journal of Ecology and Environment, 35(2), 61-71.

Hall, G.H., Patrinos, H.A., 2012. Indigenous peoples, poverty, and development. Cambridge University Press.

Hong, S.K., Kim, J.E., Ro, T.H., 2017. Island Biocultural diversity initiative for sustainable society in Asia-Pacific Island region. In. Hong, SK \& Nakagoshi, N (Eds). Landscape Ecology for Sustainable Society, Springer, pp.23-37.

Hong, S.K., \& Hakim, L., 2018. Survey Report: Natural Resource Use, Environmental Management and the Minorities in Indonesian Islands. Journal of Marine and Island Cultures, 7(2); 108-116.

Howes, M., 1979. The uses of indigenous technical knowledge in development. The IDS Bulletin, 10(2): 12-23.

Johnston, A., 2000. Indigenous peoples and ecotourism: Bringing indigenous knowledge and rights into the sustainability equation. Tourism Recreation Research, 25(2): 89-96.

Kapoor, D., Shizha, E. 2010. Indigenous knowledge and learning in Asia/Pacific and Africa: Perspectives on development, education, and culture. Springer.

Khamung, R., 2016. The investigation of rural cultural heritage and implications to agritourism strategies for conservation in rural Chiangkhan, Thailand. Journal of Tourism and Leisure Studies, 1(1): 13-36.

Khanal, S., Shrestha, M., 2019. Agro-tourism: Prospects, importance, destinations and challenges in Nepal. Archives of Agriculture and Environmental Science, 4(4): 464-471.

Kiyono, Y., 2000. The role of slash-and-burn agriculture in transforming dipterocarp forest into Imperata grassland. In Rainforest Ecosystems of East Kalimantan (pp. 199-208). Springer, Tokyo.

Kleinman, P.J., Pimentel, D., Bryant, R.B., 1995. The ecological sustainability of slash-and-burn agriculture. Agriculture, Ecosystems \& Environment, 52(2-3): 235-249.

MacKinnon, K., Hatta, G., Mangalik, A., Halim, H., 1996. The ecology of Kalimantan (Vol. 3). Oxford University Press.

Mardiany, M. 2017. Tourism in Samarinda City, East Kalimantan: recent status and future directions. Journal of Indonesian Tourism and Development Studies, 5(1): 41-48. 
Padoch, C., Pinedo-Vasquez, M., 2010. Saving slash-and-burn to save biodiversity. Biotropica, 42(5), 550-552.

Polosakan, R., Soedjito, H., 1997. Ethnobotany and home garden design in a Kenyah Dayak village on the Upper Bahau River in East Kalimantan. People and Plants of Kayan Mentarang, eds. KW Sorensen and B. Morris, 123-132.

Ramirez, C. R., 2007. Ethnobotany and the loss of traditional knowledge in the 21st century. Ethnobotany Research and Applications, 5: 245247.

Ramsey, M., Schaumleffel, N.A., 2006. Agritourism and rural economic development. Indiana Business Review, 81(3): 6-9.

Rahu, A. A., Hidayat, K., Ariyadi, M., Hakim, L., 2013. Ethnoecology of Kaleka: Dayak's agroforestry in Kapuas, Central Kalimantan Indonesia. Research Journal of Agriculture and Forestry Sciences. 1(8): 5-12.

Reyes-García, V., Guèze, M., Luz, A. C., Paneque-Gálvez, J., Macía, M. J., Orta-Martínez, M., Rubio-Campillo, X., 2013. Evidence of traditional knowledge loss among a contemporary indigenous society. Evolution and Human Behavior, 34(4): 249-257.

Schiller, A., 2001. Pampang culture village and international tourism in East Kalimantan, Indonesian Borneo. Human organization, 60(4): 414422.

Sen, B., 2005. Indigenous knowledge for development: Bringing research and practice together. The International Information \& Library Review, 37(4): 375-382.

Sznajder, M., Przezbórska, L., Scrimgeour, F., 2009. Agritourism. Cabi.

Tinker, P. B., Ingram, J. S., Struwe, S., 1996. Effects of slash-and-burn agriculture and deforestation on climate change. Agriculture, Ecosystems \& Environment, 58(1): 13-22.

Warren, D.M., 1996. Indigenous knowledge, biodiversity conservation and development. Sustainable development in third world countries: Applied and theoretical perspectives, 81-88.

Yadav, P. K., Kapoor, M., Sarma, K., 2012. Impact of Slash-And-Burn Agriculture on Forest Ecosystem in Garo Hills Landscape of Meghalaya, North-East India. J. Biodivers. Manage. Forestry 1: 1-6. 